Original Article

\title{
PROPHYLACTIC LIPID LOWERING EFFECTS OF AQUEOUS EXTRACT OF EMILIA PREATEMISSA ON CARBON TETRACHLORIDE (CCL4)-INDUCED HYPERLIPIDEMIC ALBINO RATS
}

\author{
YEMISI RUFINA ALLI SMITH', BUKOLA TOLA ALUKOㄹ, SAMUEL IDOWU FAYOMI ${ }^{1}$, OLAJUMOKE OMOLARA OJO \\ ${ }^{1}$ Department of Biochemistry, Faculty of Science, Ekiti State University, Nigeria \\ Email: yemisi.allismith@eksu.edu.ng
}

Received: 14 Dec 2020, Revised and Accepted: 12 Apr 2021

\begin{abstract}
Objective: Hyperlipidemia has been described as one of the greatest risk factors contributing to the prevalence and severity of cardiovascular diseases which has been identified as a primary cause of death. This study evaluates the lipid-lowering effects of aqueous extract of Emilia praetermissa (EP) leaves.

Methods: The investigation was carried out on rats induced with Carbon tetrachloride $\left(\mathrm{CCl}_{4} 1 \mathrm{ml} / \mathrm{kg}\right.$ body weight), pretreated with the aqueous extracts of Emilia praetermissa and then compared with a standard hypolipidemic drug, Simvastatin. The effects of Emilia praetermissa on the lipid profile were assessed by measuring the levels of total cholesterol, triglyceride, low-density lipoprotein (LDL) cholesterol, high-density lipoprotein (HDL) cholesterol. The effect on HMGCoA Reductase and Lecithine Cholesterol Acyltransferase (LCAT), which are important enzymes in lipid metabolism were also evaluated in the plasma, liver and heart of albino rats.
\end{abstract}

Results: Administration of 50, 100 and $200 \mathrm{mg} / \mathrm{kg}$ doses of aqueous extract of Emilia praetermissa leaves led to a significant reduction $(P<0.05)$ in total cholesterol, LDL cholesterol, triglyceride levels and a significant increase $(P<0.05)$ in HDL cholesterol in the tissues in a manner close to that of Normal and Standard control group. Emilia praetermissa aqueous extract led to a significant increase $(P<0.05)$ in the activity of LCAT and inhibition of HMGCoA reductase.

Conclusion: These results suggest that Emilia praetermissa leaves could play a cardioprotective role and probably serve as a new potential natural product for the management of hyperlipidema. Further investigations are warranted to elucidate the mechanism of its lipid-lowering action.

Keywords: Hyperlipidemia, Emilia praetermissa, Lipid Profile, HMG-CoA reductase, LCAT

(C) 2021 The Authors. Published by Innovare Academic Sciences Pvt Ltd. This is an open access article under the CC BY license (https://creativecommons.org/licenses/by/4.0/) DOI: https://dx.doi.org/10.22159/ijpps.2021v13i6.40500. Journal homepage: https://innovareacademics.in/journals/index.php/ijpps.

\section{INTRODUCTION}

In recent time, there has been a great deal of interest in the use of herbal remedies for treatment of human ailments. These remedies are used based on the fact that these medicines contain a large amount of natural substances which alleviate illness and promote health. World Health Organization (WHO) reported that more than $80 \%$ of the world population depends on traditional medicines for primary health care and they utilize the plant extracts or bioactive components present in them [1]. Hyperlipidemia is considered as one of the major risk factors causing cardiovascular diseases (CVDs). CVDs accounts for one third of total deaths around the world, it is believed that CVDs will turn out to be the main cause of death and disability worldwide by the year 2020 [2, 3]

Abnormal high dietary cholesterol which leads to hypercholesterolemia is strongly associated with cardiovascular diseases because it promotes atherosclerosis [4]. Indeed, it has been demonstrated that the development of coronary artery disease (CAD) is a function of the particle size of LDL-C and HDL-C, with the small particle size exhibiting great atherogenic potential [5]. Abundant evidence has accumulated relating the concentrations of lipids (total cholesterol and triglycerides) and their associated blood transporting lipoproteins (HDL-C, LDL-C, VLDL-C) with the occurrence of atherosclerosis in general and coronary artery disease (CAD) in particular. The strong association between the risk of coronary artery diseases (CAD), high levels of LDL-C and low levels of HDL-C has been well established [5]

The enzyme HMG-CoA reductase plays a vital role in the de novo cholesterol synthesis by catalyzing the conversion of 3-hydroxy-3methylglutaryl-CoA (HMG-CoA) to mevalonate, a rate-limiting step. Inhibition of HMG-CoA reductase alters the synthesis of cholesterol, proving beneficial in hypercholesterolemic conditions [6]. There are several drugs for the treatment of hypercholesterolemia which are majorly HMG CoA reductase inhibitors and most of these cholesterol lowering drugs are associated with some side effects; medicinal plants are being explored as natural hypocholesterolemic agents [6]

Emilia praetermissa is a species of flowering plant in the asteraceae family. It is a straggling herb common in farmlands and open cool places in the forest, especially along paths and roadsides. It is a forest plant distributed throughout western, central and southeast Africa [7]. In Nigeria, it is called (Igbo= nti-ele; Yoruba=0dundun) Emilia pratermissa is a useful plant of west tropical Africa generally used as food and medicine for general healing. In West Africa the leaves are occasionally eaten as a vegetable, either fresh in salads or cooked. This study was designed to evaluate the preventive and curative lipid-lowering effect of Emilia pratermissa as a source of a potential drug for the management of hyperlipidemia.

\section{MATERIALS AND METHODS}

\section{Sample collection}

The Emilia praetermissa (Milne Redh) leaves were harvested beside College of Health Technology in Ijero-Ekiti and it was identified at the Herbarium section of Plant Science and Biotechnology Department, Ekiti State University, Ado-Ekiti, Nigeria. A voucher specimen was deposited in the Departmental Herbarium with this voucher Number: UHAE-2017/105.

\section{Apparatus/Equipment and reagents}

Standard apparatus and equipment were used for the study. Standard chemicals and reagent kits was purchased from Randox Laboratories and Fortress kit, which was of analytical grade.

\section{Aqueous extract preparation}

The leaves of Emilia praetermissa was air-dried at room temperature, pulverized with an electric blender and then stored in a plastic container in the laboratory prior to analysis. The powdered leaves were extracted with $100 \mathrm{~g}$ in $1000 \mathrm{ml}$ of distilled water for $72 \mathrm{~h}$ as described by the method of Faroog [8] 


\section{Experimental rats}

Adult female albino Wistar rats, weighing 150-200g each were purchased from the breeding colony of Department of Biochemistry, Ekiti State University College of Medicine. They were acclimatized at $25{ }^{\circ} \mathrm{C}$, on a $12 \mathrm{~h}$ light $/ 12 \mathrm{~h}$ dark cycle for 2 weeks before the experiment. The handling was guided by NIH Guide for the care and use of laboratory animals, and the ethical Committee for Animal Experimentation of the Ekiti State University.

\section{$\mathrm{CCl}_{4}$ preparation and induction}

Carbon tetrachloride $\left(\mathrm{CCl}_{4}\right)$ was diluted with olive oil in ratio $1: 1$ dilution and $1 \mathrm{ml} / \mathrm{kg}$ body weight was administered intraperitonially, to induce hyperlipidemia. The $\mathrm{CCl}_{4}$ dose followed was according to the dose that can induce oxidative stress as described by [9].

\section{Experimental design}

The animals were pre-treated with aqueous extract of Emilia praetermissa for a period of 19days before $\mathrm{CCl}_{4}$ induction. The $\mathrm{CCl}_{4}$ was given as a single acute dose after 19days of pretreatment with the extract and the animals were observed for $48 \mathrm{~h}$ before they were sacrificed on the $21^{\text {st }}$ day of the experiment. Thirty (30) albino rats were divided into six (6) groups of five (5) rats each and subjected to different dosages of aqueous extract of Emilia praetermissa leaves: Group I (normal control) received an equivalent volume of water, group II served as Test control, Group III served as the Standard Control and received $100 \mathrm{mg} / \mathrm{kg}$ Simvastatin, Group IV received 50 $\mathrm{mg} / \mathrm{Kg}$ body weight of extract, group $\mathrm{V}$ was pre-treated with 100 $\mathrm{mg} / \mathrm{kg}$ of the extract and group VI was pre-treated with $200 \mathrm{mg} / \mathrm{Kg}$ body weight of extract orally daily. Animals were sacrificed after 21 days by cervical dislocation, the blood sample was collected into a heparinised tube and organs (Liver and Heart) were excised and homogenized and centrifuged at 6,000 rpm for $10 \mathrm{~min}$. The dose was decided afer preliminary acute and subacute toxicity studies. The authors decided to use the above doses to see the effectiveness at not too low or too high doses.

\section{Biochemical assays}

Lipid profile analysis was carried out by estimating the Total Cholesterol (TC), Triglycerides (TG), High-Density Lipoprotein cholesterol (HDL-C) and Low-Density Lipoprotein cholesterol (LDL-C) as described by [10]. The HMG-CoA reductase activity was assayed colorimetrically using the method of [11] with some modifications, Lecithine Cholesterol Acyltransferase (LCAT) was evaluated by the method of [12].

\section{Data analysis}

The results were analysed using Software Package for Social Sciences (SPSS) version 20 and the results were expressed as mean \pm standard deviation (SD) and mean $P$ values $<0.05$ were considered as significant.

\section{RESULTS}

\section{Effect of Emilia praetermissa on the levels of lipids and lipoproteins}

Tables 1,2 and 3 present the levels of total cholesterol (TC), triglycerides (TG), and low-density lipoprotein cholesterol (LDL-C) in the plasma, liver and the heart in normal and $\mathrm{CCl}_{4}$-induced rats. $\mathrm{CCl}_{4}$-induced rats showed a significant increase in the levels of TC, TG, and LDL-C in in the tissues when compared to normal control rats. Pre-treatment with Emilia praetermissa to $\mathrm{CCl}_{4}$-induced rats significantly minimized the alterations in these parameters when compared to $\mathrm{CCl}_{4}$-alone induced rats.

Table 4 shows the levels of high-density lipoproteins (HDL), in the tissues of normal and $\mathrm{CCl}_{4}$-induced rats. Rats treated with $\mathrm{CCl}_{4}$ showed a significant decrease in HDL. Pre-treatment with Emilia praetermissa to $\mathrm{CCl}_{4}$-induced rats showed subsequent increase in the levels of HDL cholesterol.

\section{Effect of Emilia praetermissa on the levels of lipid metabolic enzymes}

Table 5 and 6 show the activities of lecithin cholesterol acyl transferase (LCAT) and HMG CoA reductase in plasma, liver and heart of normal and $\mathrm{CCl}_{4}$-induced rats. A Significant decrease of the activities of LCAT in $\mathrm{CCl}_{4}$ untreated group when compared with the Normal control was noticed. E. praetermissa extract elevate the activities of LCAT significantly in the group pre-treated with 200 $\mathrm{mg} / \mathrm{kg}$ of Extract in plasma, liver and heart of the experimental rats. The notable activities of LCAT in the plasma of group treated with highest does of the extract are also similar to a standard drug $(100$ $\mathrm{mg} / \mathrm{kg}$ of Simvastatin) and the normal control group. A Significant increase in the activities of HMG-CoA reductase in $\mathrm{CCl}_{4}$ untreated group when compared with the Normal control was observed. $E$. praetermissa inhibits the activities of HMG-CoA reductase significantly in the group pre-treated with $200 \mathrm{mg} / \mathrm{kg}$ Extract in plasma, liver and heart of the experimental rats, which is also similar to the effect of the standard HMG-CoA reductase inhibitor $(100$ $\mathrm{mg} / \mathrm{kg}$ of Simvastatin) and the normal control group.

Table 1: Prophylactic effect of Emilia preatemissa aqueous extract on total cholesterol (mmol/dl) in albino rats tissues

\begin{tabular}{|c|c|c|c|c|}
\hline Groups & Treatment & Plasma & Liver & Heart \\
\hline 1 & Normal control & $65.10 \pm 6.82^{\mathrm{a}}$ & $144.41 \pm 12.42^{\mathrm{a}}$ & $40.80 \pm 3.51^{\mathrm{a}}$ \\
\hline 2 & Positive control $\left(\mathrm{CCl}_{4}\right)$ & $125.13 \pm 13.11^{b}$ & $156.97 \pm 13.50^{\mathrm{b}}$ & $46.47 \pm 3.99^{a}$ \\
\hline 3 & Standard drug (Simvastatin) & $75.81 \pm 7.94 \mathrm{c}$ & $31.92 \pm 2.74^{c}$ & $27.56 \pm 2.37^{b}$ \\
\hline 4 & Extract of $50 \mathrm{mg} / \mathrm{kg}$ & $117.53 \pm 12.32^{b}$ & $93.57 \pm 8.05^{\mathrm{d}}$ & $42.03 \pm 3.61^{\mathrm{ab}}$ \\
\hline 5 & Extract of $100 \mathrm{mg} / \mathrm{kg}$ & $94.89 \pm 9.94^{\mathrm{d}}$ & $39.70 \pm 3.41^{\mathrm{c}}$ & $38.22 \pm 3.28^{\mathrm{ab}}$ \\
\hline 6 & Extract of $200 \mathrm{mg} / \mathrm{kg}$ & $85.84 \pm 8.99^{c}$ & $37.36 \pm 3.21^{\mathrm{c}}$ & $35.14 \pm 3.02^{\mathrm{b}}$ \\
\hline
\end{tabular}

Results are mean of 5 determinations \pm Standard Deviation (SD). Using Analysis of Variance (ANOVA) and Duncan Multiple Range Test. Means with different superscript are significantly different at $(\mathrm{P}<0.05)$.

Table 2: Prophylactic effect of Emilia preatemissa on Triglyceride ( $\mathrm{mmol} / \mathrm{dl})$ in albino rats tissues

\begin{tabular}{lllll}
\hline Groups & Treatment & Plasma & Liver & Heart \\
\hline 1 & Normal control & $100.72 \pm 10.55^{\mathrm{a}}$ & $53.21 \pm 4.57^{\mathrm{a}}$ & $57.68 \pm 4.96^{\mathrm{a}}$ \\
2 & Positive control & $141.37 \pm 14.81^{\mathrm{b}}$ & $89.42 \pm 7.69^{\mathrm{b}}$ & $85.43 \pm 7.35^{\mathrm{b}}$ \\
3 & Standard drug (Simvastatin) & $110.06 \pm 11.53^{\mathrm{a}}$ & $61.04 \pm 5.25^{\mathrm{c}}$ & $62.09 \pm 5.34^{\mathrm{a}}$ \\
4 & Extract of $50 \mathrm{mg} / \mathrm{kg}$ & $118.86 \pm 12.45^{\mathrm{a}}$ & $81.99 \pm 7.05^{\mathrm{b}}$ & $70.44 \pm 6.06^{\mathrm{c}}$ \\
5 & Extract of $100 \mathrm{mg} / \mathrm{kg}$ & $113.12 \pm 11.85^{\mathrm{a}}$ & $74.36 \pm 6.39^{\mathrm{ac}}$ & $67.65 \pm 5.82^{\mathrm{a}}$ \\
6 & Extract of $200 \mathrm{mg} / \mathrm{kg}$ & $107.49 \pm 11.26^{\mathrm{a}}$ & $68.68 \pm 5.91^{\mathrm{c}}$ & $66.98 \pm 5.76^{\mathrm{a}}$ \\
\hline
\end{tabular}

Results are mean of 5 determinations \pm Standard Deviation (SD). Using Analysis of Variance (ANOVA) and Duncan Multiple Range Test. Means with different superscripts are significantly different at $(\mathrm{P}<0.05)$. 
Table 3: Prophylactic effect of Emilia preatemissa on low density lipoprotein cholesterol (mmol/dl) in albino rats tissues

\begin{tabular}{|c|c|c|c|c|}
\hline Groups & Treatment & Plasma & Liver & Heart \\
\hline 1 & Normal control & $54.14 \pm 5.67^{a}$ & $66.97 \pm 5.76^{a}$ & $28.90 \pm 6.89^{a}$ \\
\hline 2 & Positive control & $98.36 \pm 10.31^{b}$ & $99.53 \pm 8.56^{b}$ & $56.03 \pm 13.37^{b}$ \\
\hline 3 & Standard drug (Simvastatin) & $65.91 \pm 6.90^{c}$ & $79.78 \pm 6.86^{c}$ & $37.08 \pm 8.85^{c}$ \\
\hline 4 & Extract of $50 \mathrm{mg} / \mathrm{kg}$ & $80.04 \pm 8.39 \mathrm{~b}$ & $90.2 \pm 7.76^{b}$ & $37.51 \pm 8.95^{c}$ \\
\hline 5 & Extract of $100 \mathrm{mg} / \mathrm{kg}$ & $74.92 \pm 7.85^{\mathrm{c}}$ & $84.23 \pm 7.24^{\mathrm{c}}$ & $33.43 \pm 7.97 \mathrm{ac}$ \\
\hline 6 & Extract of $200 \mathrm{mg} / \mathrm{kg}$ & $55.58 \pm 5.82^{\mathrm{a}}$ & $77.09 \pm 6.63^{\mathrm{ac}}$ & $29.25 \pm 6.98^{\mathrm{a}}$ \\
\hline
\end{tabular}

Results are mean of 5 determinations \pm Standard Deviation (SD). Using Analysis of Variance (ANOVA) and Duncan Multiple Range Test. Means with different superscripts are significantly different at $(\mathrm{P}<0.05)$.

Table 4: Prophylactic effect of Emilia preatemissa on high density lipoprotein cholesterol (mmol/dl) in albino rats tissues

\begin{tabular}{|c|c|c|c|c|}
\hline Groups & Treatment & Plasma & Liver & Heart \\
\hline 1 & Normal control & $112.35 \pm 16.26^{\mathrm{a}}$ & $62.61 \pm 5.38^{a}$ & $49.11 \pm 4.22^{a}$ \\
\hline 2 & Positive control & $64.19 \pm 9.29^{b}$ & $30.35 \pm 2.61^{b}$ & $30.51 \pm 2.62^{b}$ \\
\hline 3 & Standard drug (Simvastatin) & $119.52 \pm 17.30^{a}$ & $59.93 \pm 5.15^{\mathrm{a}}$ & $43.80 \pm 3.76^{\mathrm{a}}$ \\
\hline 4 & Extract of $50 \mathrm{mg} / \mathrm{kg}$ & $72.38 \pm 10.48^{b}$ & $33.12 \pm 2.85^{b}$ & $34.96 \pm 3.00^{\mathrm{b}}$ \\
\hline 5 & Extract of $100 \mathrm{mg} / \mathrm{kg}$ & $92.43 \pm 13.38^{a}$ & $39.28 \pm 3.38^{b}$ & $42.73 \pm 3.67^{a}$ \\
\hline 6 & Extract of $200 \mathrm{mg} / \mathrm{kg}$ & $104.27 \pm 15.09^{a}$ & $50.27 \pm 4.32^{\mathrm{a}}$ & $51.38 \pm 4.42^{\mathrm{a}}$ \\
\hline
\end{tabular}

Results are mean of 5 determinations \pm Standard Deviation (SD). Using Analysis of Variance (ANOVA) and Duncan Multiple Range Test. Means with different superscripts are significantly different at $(\mathrm{P}<0.05)$.

Table 5: Prophylactic effect of Emilia preatemissa on LCAT (Unit/mg protein) in albino rats tissues

\begin{tabular}{|c|c|c|c|c|}
\hline Groups & Treatment & Plasma & Liver & Heart \\
\hline 1 & Normal control & $10.86 \pm 1.13^{a}$ & $15.38 \pm 1.32^{\mathrm{a}}$ & $5.98 \pm 0.51^{\mathrm{a}}$ \\
\hline 2 & Positive control & $7.70 \pm 0.80^{b}$ & $9.34 \pm 0.80^{\mathrm{b}}$ & $3.84 \pm 0.33^{b}$ \\
\hline 3 & Standard drug (Simvastatin) & $9.85 \pm 1.03^{\mathrm{a}}$ & $13.29 \pm 1.14^{\mathrm{a}}$ & $6.26 \pm 0.53^{\mathrm{a}}$ \\
\hline 4 & Extract of $50 \mathrm{mg} / \mathrm{kg}$ & $7.85 \pm 0.82^{\mathrm{ab}}$ & $10.43 \pm 0.89 b$ & $4.21 \pm 0.36^{b}$ \\
\hline 5 & Extract of $100 \mathrm{mg} / \mathrm{kg}$ & $8.38 \pm 0.87^{a}$ & $11.23 \pm 0.96^{\mathrm{a}}$ & $4.56 \pm 0.39^{\mathrm{a}}$ \\
\hline 6 & Extract of $200 \mathrm{mg} / \mathrm{kg}$ & $9.26 \pm 0.97 \mathrm{a}$ & $13.27 \pm 1.14^{\mathrm{a}}$ & $5.52 \pm 0.47^{\mathrm{a}}$ \\
\hline
\end{tabular}

Results are mean of 5 determinations \pm Standard Deviation (SD). Using Analysis of Variance (ANOVA) and Duncan Multiple Range Test. Means with different superscripts are significantly different at $(\mathrm{P}<0.05)$.

Table 6: Prophylactic effect of Emilia preatemissa on HMG-CoA reductase (Unit/mg protein) in albino rats tissues

\begin{tabular}{|c|c|c|c|c|}
\hline Groups & Treatment & Plasma & Liver & Heart \\
\hline 1 & Normal control & $107.68 \pm 11.28^{\mathrm{a}}$ & $62.55 \pm 5.38^{a}$ & $45.94 \pm 3.95^{\mathrm{a}}$ \\
\hline 2 & Positive control & $132.45 \pm 13.88^{b}$ & $87.00 \pm 7.48^{b}$ & $57.00 \pm 4.90^{b}$ \\
\hline 3 & Standard drug (Simvastatin) & $98.35 \pm 10.30^{c}$ & $57.01 \pm 4.90^{\mathrm{a}}$ & $42.69 \pm 3.67^{a}$ \\
\hline 4 & Extract of $50 \mathrm{mg} / \mathrm{kg}$ & $117.95 \pm 12.36^{b}$ & $68.11 \pm 5.86^{a}$ & $55.92 \pm 4.81^{b}$ \\
\hline 5 & Extract of $100 \mathrm{mg} / \mathrm{kg}$ & $108.48 \pm 11.37 \mathrm{a}$ & $59.77 \pm 5.14^{a}$ & $51.46 \pm 4.42^{\mathrm{ab}}$ \\
\hline 6 & Extract of $200 \mathrm{mg} / \mathrm{kg}$ & $101.80 \pm 10.67 \mathrm{ab}$ & $54.79 \pm 4.71^{\mathrm{a}}$ & $44.71 \pm 3.84^{\mathrm{a}}$ \\
\hline
\end{tabular}

Results are mean of 5 determinations \pm Standard Deviation (SD). Using Analysis of Variance (ANOVA) and Duncan Multiple Range Test. Means with different superscript are significantly different at $(\mathrm{P}<0.05)$.

\section{DISCUSSION}

Hyperlipidemia has been the basic risk factor involved in the development of cardiovascular diseases (CVD); therefore, it becomes very important to explore the use of medicinal plants using scientific means to counter the menace of the life-threatening health condition. Elevated Total cholesterol level is a recognized and wellestablished risk factor for developing atherosclerosis and other cardiovascular diseases $[13,14]$. Therefore, a reduction in total cholesterol level reduces the risk of cardiovascular diseases. An elevated plasma triglyceride level is both an independent and synergistic risk factor for cardiovascular diseases [15]. Oxidative modification of LDL is one of the key steps in the development of atherosclerosis. The LDL-cholesterol lowering could result from an increased LDL metabolism and/or a reduced LDL-synthesis[16]. Decrease in LDL-C has been considered to reduce risk of coronary heart disease [17], while the elevated level of LDL cholesterol and decreased HDL cholesterol is a risk factor for cardiovascular disease [13] and often accompany obesity [18]. Clinical data revealed that increase in HDL cholesterol concentration decreases cardiovascular risk [19].

In this study, pre-treatment with aqueous extracts of Emilia praetermissa significantly decrease the concentrations of Total Cholesterol (TC), Triglyceride (TG) and Low-Density Lipoprotein Cholesterol when compared with $\mathrm{CCl}_{4}$ untreated group and the standard drug (100 mg/kg of simvastatin) pre-treated group. The significant increase caused by $\mathrm{CCl}_{4}$ administration was found to be reduced in the treated groups in a dose-dependent manner but the most significant was noticed in the group treated with highest dose $(200 \mathrm{mg} / \mathrm{kg})$ of the extract as the significant reduction were almost similar to both the normal control and the standard drug. However, the High-Density Lipoprotein cholesterol significantly increased in a dose-dependent manner in the groups pre-treated with extracts when compared with $\mathrm{CCl}_{4}$ untreated group. The administrations of the $200 \mathrm{mg} / \mathrm{kg}$ extract were similar to the elevated level of HDL in groups treated with $100 \mathrm{mg} / \mathrm{kg}$ of simvastatin. These results were similar to previous research by [13]. Therefore, a reduction in total 
cholesterol level reduces the risk of cardiovascular diseases. Thus, the significantly lower total cholesterol levels produced by the aqueous extract of Emilia praetermissa, revealed the ability of the extract to protect against cardiovascular diseases and could be used in its management.

The major metabolic pathway for reducing cholesterol is via conversion to bile acids or preventing the cholesterol synthesis by inhibiting the HMG CoA reductase enzyme. This result shows a significant reduction of $\mathrm{HMG}$ CoA reductase activities in the pretreated animals. This inhibition is dose-dependent between the groups. E. praetermissa inhibits most the activities of HMG-CoA reductase significantly in the group pre-treated with $200 \mathrm{mg} / \mathrm{kg}$ Extract in plasma, liver and heart of the experimental rats. The notable inhibition by the highest does of the extract is also similar to a standard HMG-CoA reductase inhibitor (100 mg/kg of Simvastatin) and the normal control group. The administration of lower dose of extract $(50 \mathrm{mg} / \mathrm{kg}$ ) slightly inhibits the enzymes activities but is not statistically significant. These results confirmed that the administration of E. praetermissa inhibits the activities of HMG-COA reductase significantly. Clinical trials have shown that the use of HMG-CoA reductase inhibitors in patients with coronary risk improved endothelial function through reduction of oxidative stress and/or up-regulation of NO activities [20].

Lecithin Cholesterol Acyltransferase (LCAT) is an enzyme that is responsible for transesterification of cholesterol and its activities were reported to be inhibited by $\mathrm{CCl}_{4}$ that resulted to hyperlipidemia. LCAT is one of the major modulators of plasma highdensity lipoprotein cholesterol (HDL-C) and plays a central role in the reverse cholesterol transport (RCT) process [21]. LCAT is a plasma enzyme that circulates mostly in association with the highdensity lipoproteins (HDL) and is responsible for the synthesis of cholesterol esters present in human plasma. Cholesterol esterification catalysed by LCAT also reduces the amount of unesterified cholesterol in plasma. The activities of LCAT was significantly reduced in the $\mathrm{CCl}_{4}$ Untreated group as compared to Normal control, groups treated with standard drugs and groups pretreated with plant extracts of different doses. E. praetermissa extract elevate the activities of LCAT significantly in the group pre-treated and treated with $200 \mathrm{mg} / \mathrm{kg}$ of the extract in plasma, liver and heart of the experimental rats. The notable activities of LCAT in the plasma of group treated with highest does of the extract were also similar to a standard drug (100 mg/kg of Simvastatin) and the normal control group. This demonstrates the increase of esterification of cholesterol which lead to the synthesis of HDL-C. LCAT plays a key role in the incorporation of free cholesterol into HDL and its transfer back to VLDL and LDL, which are later returned in liver cells [21]. Obesity is a chronic problem that has to be addressed in various ways. According to the World Health Organization (WHO), "Obesity is characterized by abnormal or excessive accumulation of body fat that can be harmful to the health." [22] Nearly all the lipid profile biochemical assay analysed indicate a significant possible protective mechanism of the Emilia praetermissa extract against the hyperlipidemia and other lipid related disorder.

\section{CONCLUSION}

The results from this study have shown that pre-treatment with aqueous extract of Emilia praetermissa leaves for three weeks significantly reduced the plasma total cholesterol concentration with its LDL-fraction. Therefore, it may be regarded as a useful therapy for hyperlipidemia lowering of circulating cholesterol. Also, the inhibition of HMG-CoA reductase by the aqueous extract of Emilia praetermissa leaves shows that it exhibits a cardioprotective effect could help prevent coronary atherosclerosis.

\section{FUNDING}

Nil

\section{AUTHORS CONTRIBUTIONS}

All authors scientifically contributed in the preparation and execution of this manuscript.

\section{CONFLICT OF INTERESTS}

The authors declare that we have no conflict of interest.

\section{REFERENCES}

1. Levy D, Brink S. In: A change of heart: how the people of framingham, massachusetts, helped unravel the mysteries of cardiovascular disease, Edited by Alfred A. Knopf, (New York); 2008. p. 268.

2. Ginghina C, Bejan I, Ceck CD. Modern risk stratification in coronary heart disease. J Med Life 2011;4:377-86.

3. Jorgensen T, Capewell S, Prescott E, Allender S, Sans S, Zdrojewski T. Population-level changes to promote cardiovascular health. Eur J Prev Cardiol 2013;20:409-21.

4. Durrington P. Dyslipidemia. Lancet 2003;362:717-31.

5. Nwagha UI, Ikekpeazu EJ, Ejezie FE, Neboh EE, Maduka IC. Atherogenic index of plasma as useful predictor of cardiovascular risk among postmenopausal women in Enugu, Nigeria. Afr J Health Sci 2010;10:248-52.

6. Reddy PV, Ahmed F, Urooj A. Inhibition of 3-hydroxy-3methylglutaryl coenzyme A (HMG-CoA) reductase in liver microsomes by Moringa oleifera. Polyphenols Int J Pharm Sci Res 2012;3:2510-6.

7. Baumann G. Photographic guide to wildflowers of Malawi. Wildlife and Environmental Society of Malawi; 2005. p. 166-7.

8. Farooq T. Phytochemical and pharmacological investigation of the leaves of Carica papaya linn (Doctoral dissertation, East West University); 2013.

9. Ritesh KR, Suganya A, Dileepkumar HV, Rajashekar Y, Shivanandiappa T. A single dose of $\mathrm{CCl}_{4}$ causes oxidative stress in rat brain. Toxicol Reports 2015;2:891-5.

10. Entaz B, Maknoon SS, Bashutosh N, Hyonok Y. Evaluation of in vitro antioxidant and in vivo antihyperlipidemic activities of methanol extract of aerial part of Crassocephalum crepidioides (Asteraceae). Trop J Pharm Res 2016;15:48-52.

11. Sadowitz B, Maier KG, Gahtan V. Basic science review: statin therapy--part I: The pleiotropic effects of statins in cardiovascular disease. Vasc Endovascular Surg 2010;44:241-51.

12. Zhang L, Wang YD, Chen WD, Wang X, Lou G, Liu N. Promotion of liver regeneration/repair by farnesoid $X$ receptor in both liver and intestine in mice. Hepatology 2012;56:2336-43.

13. Ademuyiwa O, Ugbaja RN, Idumebor F, Adebawo O. Plasma lipid profiles and risk of cardiovascular disease in occupational lead exposure in Abeokuta, Nigeria. Lip Health Dis 2005;4:19-22.

14. Maha ZR, Hanan FA, Azza AM, Ghadha IF. The antihypercholesterolemic effect of ulvan polysaccharide extracted from the green algae Ulva fasciata in aged hypercholesterolemic rats. Asian J Pharm Clin Res 2016;9:165-76.

15. Martirosyan DM, Miroshnichenko LA, Kulokawa SN, Pogojeva AV, Zoloedov VI. Amaranth oil application for heart disease and hypertension. Lip Health Dis 2007;6:1-5.

16. Joshi SC, Jain PK, Sharma P. Anti-atherosclerotic and lipidlowering effects of Cinnamamum verum in cholesterol-fed rabbits. Int J Curr Pharm Res 2017;9:75-80.

17. Rang, HP, Dale MM, Ritter JM, Moore PK. Pharmacology. $5^{\text {th }}$ ed. Elsevier: India; 2005.

18. Krauss RM, Blanche PJ, Rawlings RS, Fernstrom HS, Williams PT. Separate effects of reduced carbohydrate intake and weight loss on atherogenic dyslipidaemia. Am J Clinl Nutr 2006;83:1025-31.

19. Assmann G, Gotto Am Jr. HDL cholesterol and protective factors in atherosclerosis. Circulation 2004;109:111-8.

20. Hadi HAR, Carr SC, Al SJ. Endothelial dysfunction: cardiovascular risk factors, therapy, and outcome. Vasc Health Risk Manag 2005;1:183-98.

21. Ama M, Nya B, Nono N, Moukette M, Zacharie S, Cyril K, et al. Hypolipidemic effect and activation of lecithin cholesterol acyl transferase (LCAT) by aqueous extract of Spirulina platensis during toxicological investigation. BMC Nutr 2017;3:3-7.

22. Mouna B, Zouhair S, Pierfrancesco C, Maurizio A, Abellah F, Dalila B. Anti-obesity effect of Cannabis sativa seed flour form khla of taounate redio (Norther Morocco) in high caloric dietinduced obese mice. Asian J Pharm Clin Res 2020;13:139-44. 